\title{
SOME SPECIFICS OF COST DETERMINING OF EQUIPMENT AND MACHINES TAKING INTO ACCOUNT QUALITY DEGRADATION DUE TO WEAR
}

\begin{abstract}
Hubareva V. M.
One of the objects of merchandising research, which the cost determining has certain features and complexities, are equipment and machines of various purposes especially were in operation and having a certain percentage of wear. Determining of equipment and machines operability, percentage of wear is one of the main factors affecting the formation of the market price and its definition within all approaches to property valuation. According to forensic experts experience while performing this type of research specialists, who involve for determining of a technical condition raise questions: what kind of data should be indicated in the technical condition report in order that experts can use them while performing merchandising examination and categories of technical condition assessment and the terminology should coincide. Merchandising experts on the basis of work experience and study of special literature offered the list of such data. It includes: inventory number, name (brand), purpose, completeness (configuration, mass), date of acquisition (release date), service life (operation rate), cost at acquisition date, book value, manufacturer, main technical characteristics, technical condition, functional test, repairs information, repair costs; conclusions about possibility of further exploitation. Merchandising expert uses established percentage of wear in the network of the cost approach that provides for following consecutive actions: determining of replacement cost or reproduction of valuation object and analysis of its technical condition for determining the percentage of wear and further calculations in the network of this approach. Suitability coefficient of valuation object is used by a commodity expert for determining the value of valuation object within framework of comparative approach while selecting comparison objects.
\end{abstract}

Keywords: forensic merchandising examination, technical condition report, physical, functional and economic wear.

DOI: https://doi.org/10.32353/khrife.2018.58

УДК 620.21

I. B. Сабадаш, науковий співробітник Харківського НДІСЕ

E-mail: saba-inna@ukr.net

\section{ОСОБЛИВОСТІ ВИЗНАЧЕННЯ РИНКОВОЇ ВАРТОСТІ ОБЛАДНАННЯ, ЩО ВИКОРИСТОВУСТЬСЯ НА АТОМНИХ ЕЛЕКТРОСТАНЦІЯХ}

При визначенні ринкової вартості обладнання, щзо використовується на атомних електростанціях, експерт-товарознавецьь наштовхується на дилему з обранням і обгрунтуванням методичного підходу. Запропоновано інформаційну модель, яка дає змогу вдосконалити та підвищчити якість виконання експертиз изього напряму дослідження.

Ключові слова: ядерна енергетика, обладнання, технічна ідентифікація, витратний методичний підхід до оцінювання, метод актуалізації ичіни, індекс иін виробників. 
Проведемо невеликий екскурс по термінах і статистиці ядерної енергетики: ядерна (атомна) енергетика являє собою, по-перше, галузь науки та техніки, що розробляє методи й засоби перетворення ядерної енергії на електричну та теплову; по-друге, $є$ галуззю енергетики, що використовує ядерну енергію для електрифікації й теплофікації.

Частка ядерної енергії від загального споживання електроенергії в Україні складала на серпень 1998 р. 45,42 \%1. За кількістю ядерних реакторів Україна посідає дев'яте місце у світі та п'яте в Європі. В Україні діють 4 атомних електростанцій (АЕС) з 15 енергоблоками, одна з яких - Запорізька AEC 36 енергоблоками загальною потужністю в 6 тис. МВт $-\epsilon$ найпотужнішою в Свропі. У 2009 р. відсоток ядерної енергетики склав 48 \% від усього виробництва електроенергії в Україні².

Об'єктами дослідження для експертів-товарознавців при виконанні експертиз може бути обладнання, що використовується на енергогенеруючих українських AEC, а саме на: Запорізькій АEC, Південноукраїнській АEC (Миколаївська обл.), Рівненській АЕС, Хмельницькій АЕС. Крім того, в Україні також існують ще чотири недобудовані АЕС: Харківська АТЕЦ, Одеська АТЕЦ, Кримська АЕС, Чигиринська АЕС.

Виконання цих експертиз є досить оригінальним, оскільки обладнання, що використовується на атомних електростанціях, унікальне й виготовлено на індивідуальне замовлення. Крім того, практичні аспекти оцінювання зазначеного майна належним чином не висвітлювалися.

Ураховуючи експертну практику при визначенні ринкової вартості обладнання, що використовується на енергогенеруючих українських АЕC, експерти мають такі проблеми щодо:

- ідентифікації об'єкта дослідження;

- обрання методу дослідження;

- обгрунтування й обрання методичних підходів до оцінювання майна.

Ідентифікація об'єкта оцінки - це комплексне дослідження його стану, що дозволяє отримати повноцінне розуміння про нього не тільки на момент оцінювання, а й у ретроспективному та прогнозному періодах. Ідентифікація об'єкта оцінки означає встановлення тотожності між об'єктом, що існує в реальності, і документацією на нього 3 .

Для конкретизації наведемо приклад визначення ринкової вартості технологічного обладнання з експертної практики Харківського НДІСЕ, а саме: у 2017 р. проводилась експертиза з визначення ринкової вартості вузлів електророзподільної й контрольної апаратури (щити КТПСН) та апаратури електричної низьковольтної - загальноблочного щита постійного струму 220 В ОЩПТ у складі шаф і шинного мосту. Зазначені комплекти обладнан-

${ }^{1}$ Про затвердження Загальнодержавної програми розвитку мінерально-сировинної бази України на період до 2010 року : Закон України від 22.02.2006 № 3458-IV. [Електронний ресурс] ЛІГА: ЗАКОН ЕЛІТ.

${ }^{2}$ URL: https://uk.wikipedia.org/wiki/Ядерна_енергетика.

${ }^{3}$ Гохберг I. I. Оцінка машин і обладнання : навч.-практ. посіб. / за ред. М. Л. Лапішко; Українське товариство оцінювачів. Київ, 2014. (Бібліотека Українського товариства оцінювачів). С. 25. 
ня призначені для приймання електричної енергії трифазного змінного струму й розподілу їі між споживачами систем безпеки енергоблоку. Дата оцінки є ретроспективною та не збігається з датою поставки (2012 і 2013 р.).

Процедура визначення ринкової вартості цього обладнання включала такі етапи:

— збір і вивчення технічної документації об'єкта оцінки;

— натурне обстеження об’єкта оцінки, збір відомостей про його технічний стан;

— аналіз одержаних вихідних даних для проведення незалежної оцінки;

— опис технічних характеристик об'єкта оцінки;

— обрання підходів до розрахунку вартості об'єкта оцінки;

- розрахунок вартості об'єкта оцінки за витратним підходом;

- узгодження одержаних результатів;

- оформлення висновку експертизи.

Оскільки обладнання є специфічним, то його натурне обстеження повинно проводитися спільно з фахівцями спеціалізованих підприємств для проведення технічної ідентифікації досліджуваного майна (опису товарної номенклатури, комплектації, фактичного стану). У нашому випадку технічна ідентифікація наданих вузлів електророзподільної й контрольної апаратури (щити КТПСН) та апаратури електричної низьковольтної - загальноблочного щита постійного струму 220 В ОЩПТ проведена фахівцем ВП «Південноукраїнська АЕС» ДП НАЕК «Енергоатом».

У результаті ідентифікації встановлено:

— найменування, модель об'єктів дослідження;

- призначення та принцип дії;

— масу й габарити;

- основні технічні характеристики;

— ціноутворювальні характеристики;

— характеристики системи управління;

- комплектацію;

— рік виготовлення й пуску в експлуатацію;

- відомості про виробника;

— місце перебування об’єкта оцінки;

- його стан.

Методи, що були використані при виконанні цісї експертизи, були як загальні, так і окремий метод товарознавства. Окремий метод товарознавства - система процедур пізнання споживчої цінності товарів і визначення закономірностей ії прояву та збереження ${ }^{1}$.

Оцінка майна може виконуватися із застосуванням загальновідомих у практиці методичних підходів: дохідного, порівняльного й витратного. Зупинимось більш докладно на обгрунтуванні та обранні методичного підходу до оцінювання.

${ }^{1}$ Основи судової експертизи : навч. посіб. для фахівців, які мають намір отримати або підтвердити кваліфікацію судового експерта / авт.-уклад.: Л. М. Головченко, А. І. Лозовий, Е. Б. Сімакова-Сфремян та ін. Харків : Право, 2016. С. 256. 
Оцінювання обладнання, що використовується на атомних електростанціях, із використанням порівняльного підходу в цьому разі $є$ досить проблематичним, оскільки порівняльний підхід найбільш часто застосовується для тих видів обладнання, що мають розвинутий ринок продажів і $є$ стандартним серійним обладнанням.

Порівняння об’єктів проводиться:

— із точним аналогом;

— iз приблизним аналогом, із застосуванням коригування за відсутності точного аналога.

Як вихідна інформація можуть бути: ціни прейскурантів, каталоги виробників, каталоги дилерів, лістинги продажів; ціни пропозиції; індекси цін; інформація з джерел мережі Інтернет тощо.

Слід зазначити, що при проведенні маркетингового дослідження нам не вдалося знайти аналоги, які збігаються за своїми технічними характеристиками з вузлами електророзподільної та контрольної апаратури (щити КТПСН) та апаратури електричної низьковольтної, оскільки ринок обладнання для потреб атомних електростанцій є досить закритий в нашій країні, це, поперше, пов'язано із стратегічним статусом таких об'єктів і підвищеною системою безпеки із обмеженим доступом до них i, по-друге, потреби кожної АЕС є достатньо індивідуальними, під які розробляються власні вимоги, що відображаються в технічних умовах. Крім того, нами встановлено, що на дату проведення експертизи на території України пропонує подібне обладнання (пропонує виробництво під замовлення) саме завод - виробник обладнання, що є об'єктом оцінки. Ураховуючи те, що об'єкт оцінки - комплекти обладнання були вироблені на замовлення, тому є спеціалізованим майном, ринок якого обмежений, тому ми відмовилися від застосування в експертизі порівняльного підходу.

Отже, використання порівняльного підходу в цьому разі є неможливим, оскільки:

- відсутні аналоги продажу обладнання;

- недостатня кількість інформації щодо умов продажу;

- спеціалізованність та унікальність обладнання.

Оцінювання обладнання, що використовується на атомних електростанціях, із використанням дохідного пiдходу в нашому випадку також не може бути здійснене, оскільки дохідний підхід зазвичай не застосовується при оцінюванні індивідуальних одиниць обладнання, але може слугувати для перевірки правильності оцінювання, коли активи оцінюються як частина бізнесу.

На підставі зазначеного використання дохідного підходу при визначенні ринкової вартості вузлів електророзподільної та контрольної апаратури (щити КТПСН) та апаратури електричної низьковольтної - загальноблочного щита постійного струму 220 В ОЩПТ у складі шаф і шинного мосту в експертизі було неможливим, оскільки в основу дохідного підходу покладено прогнозування майбутніх доходів користувача та конкретний спосіб користування технологічним обладнанням, а саме: 
- важко передбачити дохід від експлуатації окремої одиниці обладнання (вузлів електророзподільної та контрольної апаратури та апаратури електричної низьковольтної);

— важко виділити дохід від експлуатації окремої одиниці обладнання із загального доходу підприємства.

Обгрунтування застосування витратного підходу. Витратний підхід переважно використовується при оцінюванні, якщо неможливо знайти об’єкт-аналог, відсутній будь-який досвід реалізації подібних об'єктів або прогноз майбутніх доходів нестабільний, середовище реалізації оцінюваного майна дуже невизначене, й успіх залежить від значної кількості факторів. Витратний підхід передбачає визначення вартості обладнання на основі калькуляції витрат, необхідних для створення або придбання, охорони, виробництва та реалізації обладнання на момент оцінки. Зважаючи на те, що на дослідження надані необхідні вихідні дані, зокрема інформація заводувиробника обладнання, яке є об'єктом оцінки, стосовно їх ціни продажу, договори на поставку, специфікації, дилерські угоди, доцільним було використання витратного підходу, а саме: визначена вартість відтворення шляхом застосування методу актуалізації ціни.

За методом актуалізації ціни вартість розраховується за такою формулою

$$
\mathrm{B}_{\mathrm{B}}=\mathrm{B}_{\mathrm{I}} \times \mathrm{K}_{\mathrm{PL}} \text {, }
$$

де $\mathrm{B}_{\mathrm{B}}$ - вартість відтворення об'єкта оцінки; $\mathrm{B}_{\mathrm{I}}$ - історична вартість; $\mathrm{K}_{\mathrm{PL}}-$ коефіцієнт, який ураховує зміну рівня цін за час від дати ціноутворення до дати оцінки в країні-виробнику.

Одним із джерел базової цінової інформації в методі актуалізації ціни є: прайс-лист, комерційна пропозиція, інші аналогічні документи, дата формування яких не збігається 3 датою оцінки ${ }^{1}$. Джерелами базової цінової інформації (історичної вартості, $\mathrm{B}_{\mathrm{I}}$ ) у нашому розрахунку використано цінову інформацію, зазначену в спеціфікаціях до договорів поставки. Крім того, на нашу думку, доцільно в експертизі зазначити таке обмеження достовірності дослідження: «Висновки цього дослідження є достовірними за дотримання такої умови: цінова інформація, зазначена в джерелах базової цінової інформації, відповідає визначенню ринкової вартості згідно з Національним стандартом № 1 “Загальні засади оцінки майна й майнових прав"2».

Відповідно до наведеної формули та специфіки оцінюваного обладнання нами прийнято рішення застосування в розрахунку індексу цін виробників промислової продукції. Індекс цін виробників промислової продукції (ІЦВ) $є$ показником зміни цін у часі у сфері промислового виробництва, який дозволяє відслідковувати та визначати тенденції змін цін як за видами еко-

\footnotetext{
${ }^{1}$ Гохберг I. I. Зазнач. твір. С. 81.

${ }^{2}$ Національний стандарт № 1 «Загальні засади оцінки майна й майнових прав» : постанова Кабінету Міністрів України від 10.09.2003 № 1440. Офіційний вісник Украӥни. 2003. № 37.
} 
номічної діяльності, так і у виробництві конкретної продукції. Він використовується при створенні інформаційної бази для прогнозування й управління процесами ціноутворення в промисловості, перерахунку показників системи національних рахунків у постійні ціни та забезпечує можливість проведення міжнародних зіставлень ${ }^{1}$.

Ураховуючі те, що дата оцінки вузлів електророзподільної та контрольної апаратури (щити КТПСН) - 14.01.2013, а базова вартість (історична вартість) об'єкта оцінки визначена на 15.12.2012, при розрахунку ринкової вартості досліджуваного обладнання доцільно застосувати індекс цін виробників промислової продукції при виробництві електричного, електронного та оптичного устаткування за грудень 2012 р. Відповідна інформація розміщена на офіційному сайті Державної служби статистики ${ }^{2}$. Отже, нами проведено розрахунок ринкової вартості технологічного обладнання вузлів електророзподільної та контрольної апаратури (щити КТПСН) станом на січень 2013 р. шляхом множення базової вартості, зазначеної в специфікації від 15.12.2012, на індекс цін виробників промислової продукції при виробництві електричного, електронного та оптичного устаткування за грудень 2012 р.

Ураховуючи те, що дата оцінки апаратури електричної низьковольтної загальноблочного щита постійного струму 220 В ОЩПТ у складі шаф і шинного мосту - 09.07.2012, а базова вартість (історична вартість) об' єкта оцінки визначена на 11.09.2012, при розрахунку ринкової вартості цього обладнання доцільно застосувати індекси цін виробників промислової продукції при виробництві електричного, електронного та оптичного устаткування за липень і серпень 2012 р., тобто нами проведено перерахунок базової вартості (історичної вартості) у поточні ціни на дату оцінки, а саме на 09.07.2012. Розрахунок ринкової вартості цього обладнання станом на липень 2012 р. проведено шляхом ділення базової вартості, зазначеної в специфікації від 11.09.2012, на відповідний індекс цін виробників промислової продукції при виробництві електричного, електронного та оптичного устаткування.

Узагальнюючи наведене, зазначимо, що при визначенні ринкової вартості обладнання, яке використовується на атомних електростанціях, експерту-товарознавцю необхідно:

- проводити натурне обстеження спільно з фахівцями спеціалізованих підприємств для проведення технічної ідентифікації досліджуваного обладнання; ства;

— використовувати як загальні методи, так і окремий метод товарознав-

- застосовувати витратний підхід до оцінювання, а саме: метод актуалізації ціни та індекси цін виробників промислової продукції (ІЦВ).

${ }^{1}$ URL: https://uk.wikipedia.org/wiki/Індекс_цін_виробників.

${ }^{2}$ URL: http://www.ukrstat.gov.ua. 


\section{ОСОБЕННОСТИ ОПРЕДЕЛЕНИЯ РЫНОЧНОЙ СТОИМОСТИ ОБОРУДОВАНИЯ, ИСПОЛЬЗУЕМОГО НА АТОМНЫХ ЭЛЕКТРОСТАНЦИЯХ}

\section{Сабадаш И. В.}

Выполнение експертиз по определению рыночной стоимости оборудования, которое используется на украинских атомных электростанциях, является довольно сложным процессом, поскольку оно является уникальным, изготовленным по индивидуальному заказу. На сегодня практические аспекты оценки указанного имущества, к сожалению, должным образом исследователями не освещались. Учитывая экспертную практику при определении рыночной стоимости оборудования, используемого на украинских атомных электростанциях, эксперты-товароведы сталкиваются с такими проблемами, как идентификация объекта исследования, выбор метода исследования, обоснование и выбор методических подходов к оценке такого имущества. Поскольку оборудование является специфическим, его натурное обследование должно проводиться совместно со специалистами специализированньх предприятий для технической идентификации исследуемого имущества (описания товарной номенклатуры, комплектации, фактического состояния). Методы, использованные при выполнении этого вида экспертиз, являются как общие, так и частные методы товароведения. Нами рекомендуется использовать при расчете рыночной стоимости затратный подход, а именно применение метода актуализацчии изены. Затратный подход преимущественно используется при оценке, если невозможно найти объект-аналог, отсутствует любой опьт реализации подобньх объектов или прогноз будущчих доходов нестабильный, среда реализаџчи очениваемого имущества очень неопределенная, и успех зависит от значительного количества факторов. Таким образом, при определении рыночной стоимости оборудования, используемого на украинских атомных электростанциях, эксперту-товароведу необходимо: проводить натурное обследование совместно со специилистами спецุиализированных предприятий для технической идентификации исследуемого имущчества; использовать как общие методы, так и частные методы товароведения; применять затратный подход к оцениванию, а именно метод актуализациии ичены, и использовать индексы цеен производителей промышленной продукиии.

Ключевые слова: ядерная энергетика, оборудование, техническая идентификацุия, затратный методический подход к очениванию, метод актуализации ичены, индекс иен производтелей.

\section{SPECIFICS OF THE MARKET VALUE DETERMINATION OF THE EQUIPMENT USED IN NUCLEAR POWER STATIONS}

\section{Sabadash I. V.}

Execution of examinations to determine the market cost of the equipment that is used on Ukrainian nuclear power stations is quite complicated process, since this equipment is unique, manufactured to individual order. For today practical aspects of the specified property estimation, unfortunately, researchers were not properly shined. Considering expert practice at definition of market cost of the equipment used on Ukrainian atomic power stations, merchandising experts face the following problems as identification of research object, choice of research method, substantiation and choice of methodical ap- 
proaches to an estimation of such property. Since the equipment is specific, its full-scale investigation should be carried out jointly with specialists of specialized enterprises for technical identification of the used property (description of the commodity nomenclature, packaging arrangement, real state). The methods used in performing this type of examination are both general and a separate method of commodity research. We recommended using the cost approach in calculating the market value, namely the application of the method of price actualization. The cost approach is mainly used at estimation if it is impossible to find object-analogue, there is no experience of realization of similar objects or the forecast of the future incomes not stable, the environment of estimated property realization very uncertain and success depends on a significant amount of factors. Therefore, in determining the market value of equipment used on Ukrainian atomic power stations, merchandising expert needs: conduct a full-scale investigation together with specialists from specialized enterprises for technical identification of the investigating property; use both general methods and a separate methods of commodity research; apply a cost approach to valuation, namely the method of price actualization and used price indices of industrial producers.

Keywords: nuclear power, equipment, technical identification, cost methodical approach to estimation, method of price actualization, prices index of manufacturers. 